\title{
ANALISIS IMPLEMENTASI LISTEN BEFORE TALK (LBT) PADA LTE-LICENSED ASSISTED ACCESS (LAA) DAN WI-FI 5 GH
}

\author{
Dilla Fajar Sukma Dilaga ${ }^{1}$, Uke Kurniawan Usman ${ }^{2}$, Doan Perdana ${ }^{3}$ \\ 1,2,3 Teknik Telekomunikasi, Fakultas Teknik Elektro, Universitas Telkom, bandung, Indonesia \\ 1dillafs@student.telkomuniversity.ac.id, 2ukeusman@telkomuniversity.ac.id, \\ 3doanperdana@telkomuniversity.ac.id
}

\begin{abstract}
Abstrak
LTE Release 13 memungkinkan penggunaan spektrum frekuensi unlicensed yang disebut dengan Licensed-Assisted Access (LAA). Pada LTE-LAA, spektrum licensed LTE digunakan sebagai primary cell untuk membawa informasi serta mengangkut trafik data. Untuk secondary cell, spektrum unlicensed $5 \mathrm{GHz}$ digunakan, yang bertujuan untuk meningkatkan kapasitas, serta pembagian spektrum secara adil. Penelitian ini menganalisa penggunaan mekanisme Listen Before Talk (LBT) pada LTE-LAA sebagai mekanisme untuk menghasilkan koeksistensi antara LTE-LAA dan Wi-Fi. Hasil simulasi skenario 1 menghasilkan indeks fairness throughput 64 pengguna untuk FTP over UDP pada skenario 1 sebesar 0.998, skenario 2 sebesar 0.857 dan skenario 3 sebesar 0.997 . Sedangkan untuk FTP over TCP pada skenario 1 sebesar 0.779, skenario 2 sebesar 0.639 dan skenario 3 sebesar 0.741 .
\end{abstract}

Kata Kunci: LTE-LAA, LBT, unlicensed, fairness.

\begin{abstract}
Evolution of LTE in releases 13 allows the use of unlicensed frequency variations called License-Assisted Access (LAA). In LTE-LAA, a combination of licensed LTE is used as primary cells to carry information traffic and transport data, whereas the $5 \mathrm{GHz}$ unlicensed spectrum is also used as secondary cells that proposed to increase capacity and distribute the spectrum fairly. The study analyzed the use of Listen Before Talk (LBT) on LTE-LAA as the mechanism to produce coexistence between LTE-LAA and Wi-Fi. The results of research simulation for FTP over UDP in throughput fairness case is 0.998 for scenario 1 , scenario 2 is 0.857 and scenario 3 is 0.997 , whereas for FTP over TCP in scenario 1 is 0.779 , scenario 2 is 0.639 and scenario 3 is 0.741 .
\end{abstract}

Key Words: LTE-LAA, LBT, unlicensed, fairness.

\section{Pendahuluan}

Jumlah pengguna smartphone yang terus meningkat, khususnya pada layanan data mengakibatkan permintaan trafik data meningkat. Jaringan 4G Long Term Evolution (LTE) menjanjikan penggunanya untuk mendapatkan user experience yang lebih baik. Namun, salah satu masalah pada layanan ini adalah lonjakan trafik data, terutama pada daerah dengan kepadatan yang tinggi. Hal ini mengakibatkan user experience yang menurun. Salah satu cara untuk memenuhi permintaan trafik yang tinggi adalah pemanfaatan spektrum frekuensi secara maksimal. Di sisi lain, Ketersediaan sumber daya spektrum frekuensi terbatas, sehingga dibutuhkan strategi penggunaan yang efektif dan efisien.

Ketersediaan spektrum frekuensi unlicensed $5 \mathrm{GHz}$ yang tinggi dapat dimanfaatkan untuk memenuhi kebutuhan spektrum frekuensi. Pemanfaatan ini dianggap 3GPP sebagai salah satu solusi untuk memenuhi tingginya permintaan trafik. LTE Release 13 memungkinkan penggunaan spektrum frekuensi unlicensed tersebut sebagai tambahan dari spektrum licensed. Dengan kata lain frekuensi unlicensed bergantung terhadap frekuensi licensed. Fitur tersebut disebut sebagai Licensed-Assisted Access (LAA) [1]. Namun terdapat jutaan perangkat 802.11 yang bekerja pada frekuensi $5 \mathrm{GHz}$ dalam berbagai penggunaan dan akan terganggu apabila tidak digunakan mekanisme pembagian yang adil. 3GPP doc. RP-141664 menyatakan, LTE-LAA harus menjadi good neighbor dan memastikan koeksistensi yang baik dan adil bagi perangkat lain pada frekuensi yang sama.

Pada LTE-LAA, metode carrier aggregation dari primary cell (beroperasi dalam licensed spectrum) digunakan untuk menyampaikan informasi penting dan menjamin Quality of Service (QoS), sedangkan secondary cell (beroperasi dalam unlicensed spectrum) untuk meningkatkan laju data secara oportunis (supplemental downlink). Mekanisme Listen Before Talk 
(LBT) juga digunakan untuk memastikan koeksistensi yang adil secara global. Jaringan LTE-LAA akan menghasilkan semakin banyak small cell untuk mengakomodasi pelanggan yang padat.

Pada penelitian [2], penggunaan spektrum unlicensed untuk jaringan LAA harus diikuti dengan mekanisme koeksistensi yang baik, sehingga tidak mengganggu perangkat 802.11 lainnya. Mekanisme koeksistensi 802.11 memanfaatkan Energy Detection (ED) pada thresholds tinggi dan Carrier Sense (CS) pada thresholds rendah. 3GPP doc. RP-141664 [3] menyatakan bahwa tidak boleh mempengaruhi layanan Wi-Fi (data, video dan layanan voice) itu sendiri. Pada penelitian [4][5][6], Mekanisme LBT digunakan tanpa mempertimbangkan perubahan jumlah pengguna, indeks fairness antara LAA dan Wi-Fi. Dua (2) skenario yang dilakukan, yaitu operator Wi-Fi dengan Wi-Fi serta operator LAA dengan Wi-Fi.

Penelitian ini dilakukan untuk mengetahui pengaruh penggunaan mekanisme LBT pada LTE-LAA terhadap Wi-Fi pada frekuensi $5 \mathrm{GHz}$, serta untuk dapat menganalisis kinerja layanan LBT LTE-LAA berdasarkan parameter integrity Key Performance Indicator (KPI) yaitu throughput dan latency untuk setiap skenario beserta fairness dari hasil simulasi. Simulasi dilakukan dengan menggunakan variabel yang berbeda, di antaranya adalah jumlah perangkat, energy detection threshold, user arrival time ( $\lambda)$ dan penggunaan 3 skenario simulasi, sehingga dapat diamati efektifitas penggunaan mekanisme LBT.

\section{Landasan Teori}

\subsection{LTE-Licensed Assisted Access (LAA)}

LAA adalah teknologi LTE-Advanced yang dapat meningkatkan kecepatan data pengguna dan mengurangi kepadatan trafik. LAA adalah sebuah sistem yang direncanakan menggunakkan tambahan $5 \mathrm{GHz}$ unlicensed band (supplemental downlink), dengan primary cell (PCell) yang selalu beroperasi pada licensed band. LTE-LAA bekerja dengan memanfaatkan spektrum unlicensed, sehingga dapat memenuhi permintaan trafik yang terus meningkat. Spektrum frekuensi unlicensed $5 \mathrm{GHz}$ pada LAA dipilih dikarenakan ketersediaan kanal yang lebih banyak dibanding 2.4 GHz. Oleh karena itu, kinerja layanan akan lebih baik sebab ketersediaan perangkat pada frekuensi $5 \mathrm{GHz}$ akan lebih sedikit. Alasan lainnya karena interferensi yang terjadi pada frekuensi $5 \mathrm{GHz}$ lebih rendah daripada $2.4 \mathrm{GHz}$. Namun, baik frekuensi $2.4 \mathrm{GHz}$ maupun $5 \mathrm{GHz}$ digunakan untuk perangkat Wi-Fi 802.11. Sehingga, terdapat jutaan perangkat 802.11 yang bekerja pada frekuensi $5 \mathrm{GHz}$ dan akan terganggu apabila tidak menggunakan mekanisme pembagian yang adil.

\subsection{Wi-Fi}

Wi-Fi adalah akronim dari Wireless Fidelity dimana jaringan ini mengacu pada jenis komunikasi IEEE 802.11 Wireless Local Area Network (WLAN). WLAN merupakan perluasan jaringan Local Area Network (LAN) dengan menyediakan konektivitas jaringan nirkabel. Dengan arsitektur jaringan tanpa kabel, WLAN sangat popular untuk menyediakan konektivitas IP di perumahan, perkantoran dan lingkungan kampus. Saat ini, WLAN telah berkembang dan menjadi bagian penting dalam jaringan komputer [7].

\subsection{Listen Before Talk (LBT)}

LTE-LAA bekerja pada band frekuensi unlicensed $5 \mathrm{GHz}$, sehingga dibutuhkan penyesuaian mekanisme dengan perangkat sejenis pada frekuensi yang sama. IEEE sebagai badan standarisasi perangkat 802.11 mewajibkan semua perangkat pada frekuensi $5 \mathrm{GHz}$ untuk menggunakan protokol Carrier-Sense Multiple Access (CSMA). Penggunaan protokol CSMA digunakan untuk memperoleh LBT.

\section{LTE-LAA}

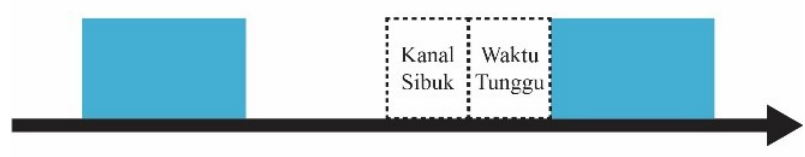

Wi-Fi

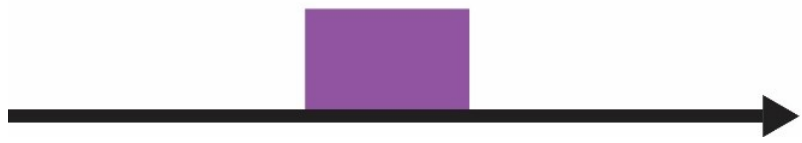

Gambar 1. Mekanisme LBT

Gambar 1 menunjukan mekanisme LBT pada LAA terhadap Wi-Fi. LBT adalah prosedur pengiriman dengan konsep apabila tidak termasuk dalam kategori Clear Channel Available (CCA). Maka LAA akan mengirim data, sedangkan apabila kanal penuh maka akan ada proses tunggu. Dengan kata lain, LBT adalah mekanisme penggunaan kanal adil, sehingga apabila kanal sedang digunakan maka pengguna lain harus menunggu [6].

\subsection{Key Performance Indicator (KPI)}

QoS pada layanan seluler biasa disebut sebagai KPI. KPI merupakan evaluasi kerja dari layanan nirkabel sebagai acuan atau tolak ukur kinerja jaringan. KPI digunakan dalam Radio Access Network (RAN) untuk mengukur kontribusi terhadap persepsi pelanggan pada kualitas dan kinerja sistem. Latency disebut juga delay atau jeda waktu yang dibutuhkan dalam pengiriman paket dari pengirim ke pengguna (1). Throughput adalah 
kecepatan dimana paket dapat ditransfer sejak paket pertama dijadwalkan pada air interface (2).

$$
\begin{array}{r}
\text { DLLatency }[m s]=\frac{P m P d c p L a t T i m e D L}{\text { pmPdcpLatPktTransDL }} \\
\text { DLThroughput }[\text { Byte } / s]=\frac{V t p D L}{\text { TtpDL }}
\end{array}
$$

dimana,

PmPdcpLatTimeDL = Downlink latency gabungan untuk periode waktu pengukuran.

pmPdcpLatPktTransDL = Jumlah paket untuk pegukuran latency downlink selama periode pengukuran.

VtpDL = volume pada level IP.

TtpDL = waktu yang telah berlalu di Uu untuk pengiriman volume.

\subsection{Jains Fairness Index}

Keadilan adalah salah satu aspek yang penting dalam jaringan nirkabel untuk pembagian atau alokasi sumber daya. Konsekuensi dari alokasi sumber daya yang tidak adil menyebabkan pemborosan sumber daya atau alokasi yang berlebihan. Jains index merupakan salah satu metode fairness yang dapat digunakan, nilai index fairness yang baik adalah mendekati 1(3).

$$
\text { Jain's Fairness Index }=f(x)=\frac{\left(\sum_{i=1}^{n} s_{i}\right)^{2}}{n\left(\sum_{i=1}^{n} x_{i^{2}}\right)}
$$

Dimana:

$n=$ jumlah data

$x_{i}=$ normalized throughput

\subsection{Network Simulator 3}

Network Simulator 3 (NS-3) adalah aplikasi simulasi jaringan discrete-event, ditargetkan terutama untuk penelitian dan penggunaan pendidikan. NS-3 adalah perangkat lunak gratis, dilisensikan dibawah lisensi GNU GPLv2, dan tersedia secara publik untuk penelitian, pengembangan, dan penggunaan. Tujuan pembuatan NS-3 adalah untuk mengembangkan lingkungan simulasi terbuka untuk penelitian jaringan. Simulasi NS-3 mendukung penelitian jaringan berbasis IP dan non-IP. Namun, sebagian besar penggunanya berfokus pada simulasi nirkabel/IP yang melibatkan model Wi-Fi, WiMAX atau LTE untuk layer 1 dan 2 dan berbagai routing statis atau dinamis [8].

\section{Pemodelan Sistem}

\subsection{Perencanaan Simulasi}

Penelitian dimulai dengan pengumpulan data dan terkait perencanaan Wi-Fi model, LAA model dengan mekanisme LBT dan traffic model. Setelah data terkumpul dan diolah, maka dilakukan proses pemodelan LBT pada LTE-LAA. Tahapan selanjutnya dilakukan proses simulasi yang akan dilakukan pada software Network Simulator-3 (NS-3), yang terbagi menjadi 3 skenario. Setiap skenario dilakukan tanpa penerapan LBT (before) dan penerapan mekanisme LBT (after). Dari hasil simulasi, nilai KPI integrity dilihat dengan menggunakan module FlowMonitor pada NS-3. Selanjutnya, analisis data dilakukan dan dilihat perbandingan antara 3 skenario tersebut. Hasil simulasi dari 3 skenario yang dilakukan digunakan untuk mendapatkan nilai indeks fairness sehingga dapat dilihat pengaruh penggunaan LBT pada LAA terhadap Wi-Fi.

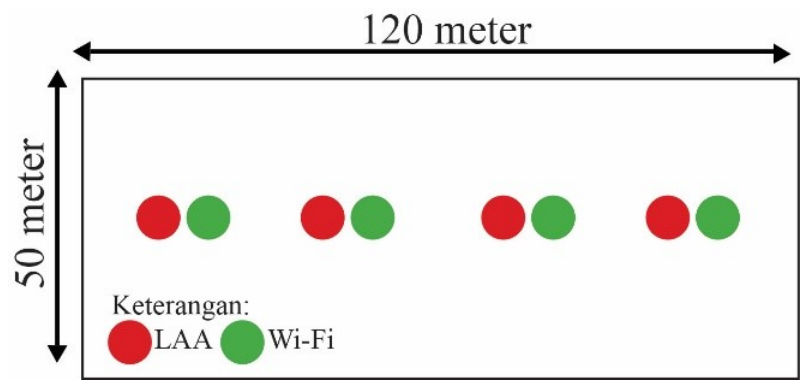

Gambar 2. Layout Perencanaan Simulasi

Gambar 2 menunjukan layout perencanaan simulasi dilakukan dengan menggunakan 2 operator, yang terdiri dari operator A (LAA) dan operator B (Wi-Fi). Node tersebut terletak pada ruangan dengan panjang 120 meter dan lebar 50 meter tanpa memperhitungkan loss bangunan. Node operator A secara berturut-turut berada pada koordinat $(20,25),(45,25),(70,25),(95,25)$, sedangkan operator B berada pada koordinat $(20+$ bsSpacing, 25), (45 + bsSpacing, 25), (70 + bsSpacing, 25), (95 + bsSpacing, 25). bsSpacing merupakan jarak antar node pada operator berbeda. Penambahan jarak berpengaruh pada peluang interferensi yang semakin kecil. Nilai bsSpacing ini adalah 5 meter, namun dapat diatur untuk mendapatkan hasil yang terbaik.

\section{Tabel 1. Parameter Simulasi pada NS-3}

\begin{tabular}{|l|l|}
\hline \multicolumn{1}{|c|}{ Parameter } & \multicolumn{1}{c|}{ Nilai } \\
\hline Bandwidth Sistem & $20 \mathrm{MHz}$ \\
\hline Carrier Frequency & $5 \mathrm{GHz}$ (channel 36) \\
\hline Jumlah Pengguna & 16,40 dan 64 \\
\hline Transport Protokol & TCP dan UDP \\
\hline Jarak antar Operator & 5 meter \\
\hline Traffic Model & $\begin{array}{l}\text { FTP Model 1 as in TR36.814. } \\
\text { FTP model file size: } 0.5 \text { Mbytes } \\
=0.5,1.5 \text { dan } 2.5\end{array}$ \\
\hline CCA-ED & $-62,-72$ dan $-82 \mathrm{dBm}$ \\
\hline
\end{tabular}

Dari Tabel 1 dapat dilihat bahwa simulasi LTE-LAA menggunakan bandwidth sebesar $20 \mathrm{MHz}$. Jumlah pengguna sebanyak 16, 40 dan 64 pada masing-masing skenario. File Transfer Protocol (FTP) Model 1 adalah tipe traffic dengan menggunakan 
protokol FTP berdasarkan ukuran file dan waktu tiba packet data pada setiap cell. Clear Channel Available-Energy Detection (CCA-ED) memungkinkan penerima untuk mendeteksi energi non-Wi-Fi di kanal operasi. Adapun nilai CCA-ED yang digunakan pada simulasi ini berkisar pada $-62 \mathrm{dBm},-72 \mathrm{dBm}$ dan -82 $\mathrm{dBm}$.

\subsection{Skenario Simulasi}

Tabel 2. Perbandingan Simulasi 3 Skenario Uji

\begin{tabular}{|l|c|c|c|}
\hline \multicolumn{1}{|c|}{ Parameter } & Skenario 1 & Skenario 2 & Skenario 3 \\
\hline Bandwidth & $20 \mathrm{MHz}$ & $20 \mathrm{MHz}$ & $20 \mathrm{MHz}$ \\
\hline $\begin{array}{l}\text { Carrier } \\
\text { Frequency }\end{array}$ & $5 \mathrm{GHz}$ & $5 \mathrm{GHz}$ & $5 \mathrm{GHz}$ \\
\hline $\begin{array}{l}\text { Transport } \\
\text { Protocol }\end{array}$ & $\begin{array}{c}\text { TCP dan } \\
\text { UDP }\end{array}$ & $\begin{array}{c}\text { TCP dan } \\
\text { UDP }\end{array}$ & $\begin{array}{c}\text { TCP dan } \\
\text { UDP }\end{array}$ \\
\hline $\begin{array}{l}\text { ED } \\
\text { Threshold }\end{array}$ & $-62 \mathrm{dBm}$ & $-62 \mathrm{dBm}$ & $-72 \mathrm{dBm}$ \\
\hline $\begin{array}{l}\text { User } \\
\text { Arrival Time }\end{array}$ & 2.5 & 2.5 & 0.5 \\
\hline Duty Cycle & 1 & 0 & - \\
\hline $\begin{array}{l}\text { Number } \\
\text { of User }\end{array}$ & $\begin{array}{c}16,40 \\
\text { dan } 64\end{array}$ & $\begin{array}{l}16,40, \\
\text { dan 64 }\end{array}$ & $\begin{array}{c}16,40, \\
\text { dan } 64\end{array}$ \\
\hline Mechanism & Duty Cycle & Duty Cycle & LBT \\
\hline
\end{tabular}

Dari Tabel 2 dapat dilihat perbandingan simulasi antar skenario yang dilakukan. Pada skenario 1, digunakan energy detection threshold $-62 \mathrm{dBm}$, user arrival time $(\lambda)$ sebesar 2.5 , duty cycle sebesar 1 dengan penggunaan mekanisme duty cycle. Pada skenario 2 digunakan energy detection threshold $-62 \mathrm{dBm}$, user arrival time $(\lambda)$ sebesar 2.5 , duty cycle sebesar 2 dengan penggunaan mekanisme duty cycle. Pada skenario 3, digunakan energy detection threshold sebesar $-72 \mathrm{dBm}$, user arrival time $(\lambda)$ sebesar 0.5 dengan penggunaan mekanisme LBT. Setiap skenario di atas dilakukan dengan memperhatikan variabel jumlah pengguna yang beragam yaitu 16, 40 dan 64 total pengguna. File Transfer Protocol (FTP) adalah protokol yang berfungsi untuk tukar-menukar file dalam suatu jaringan. Simulasi dilakukan berdasarkan FTP model 1 [9] dimana nilai user arrival time $(\lambda)$ berkisar antara 0.5 sampai 2.5 .

Energy detection (ED) threshold adalah $20 \mathrm{~dB}$ diatas signal detection threshold (4). Signal detection (SD) threshold secara statistik adalah $4 \quad \mathrm{~dB}$ Signal-to-Noise Ratio (SNR) untuk mendeteksi preamble 802.11(5). ED threshold digunakan untuk mendeteksi tipe transmisi RF lain ketika CCA sedang berlangsung.

$$
\begin{aligned}
& S D=4 d B S N R \\
& E D=S D+20 d B
\end{aligned}
$$

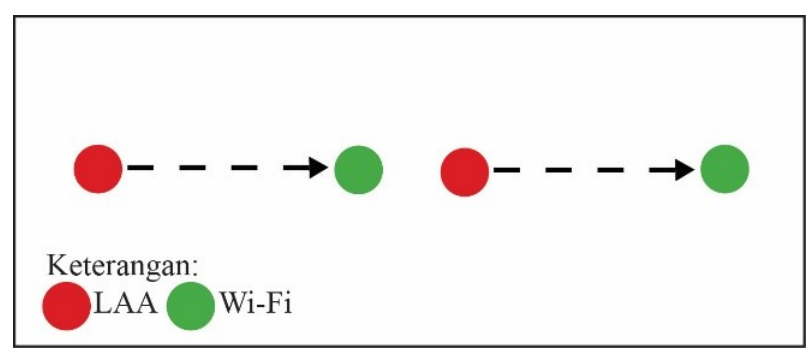

Gambar 3. Ilustrasi LAA menginterferensi Wi-Fi

\subsubsection{LAA menginterferensi Wi-Fi}

Gambar 3 menunjukan ilustrasi skenario 1 dengan anggapan bahwa operator A (LAA) sebagai sumber interferensi operator B (Wi-Fi). Skenario ini bertujuan sebagai acuan sistem Wi-Fi yang performanya melemah terhadap LAA jika tidak menggunakan mekanisme LBT.

\subsubsection{Wi-Fi menginterferensi LAA}

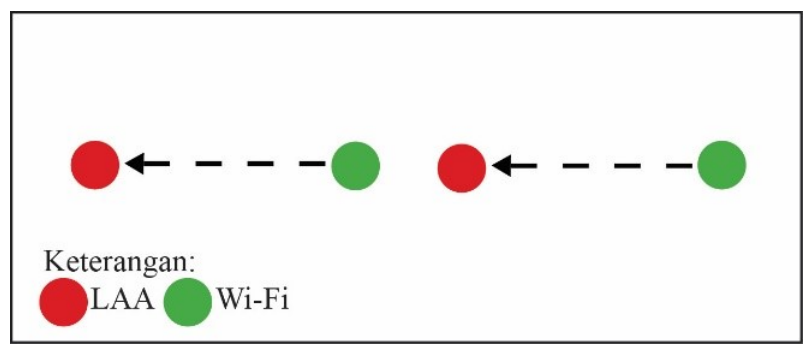

Gambar 4. Ilustrasi W-Fi menginterferensi LAA

Gambar 4 menunjukan ilustrasi skenario 2 dengan anggapan bahwa operator $\mathrm{B}$ (Wi-Fi) sebagai sumber interferensi operator A (LAA). Skenario ini bertujuan sebagai acuan sistem LAA yang performanya melemah terhadap Wi-Fi jika tidak menggunakan mekanisme LBT.

\subsubsection{Skenario Ideal (Penerapan LBT pada LAA)}

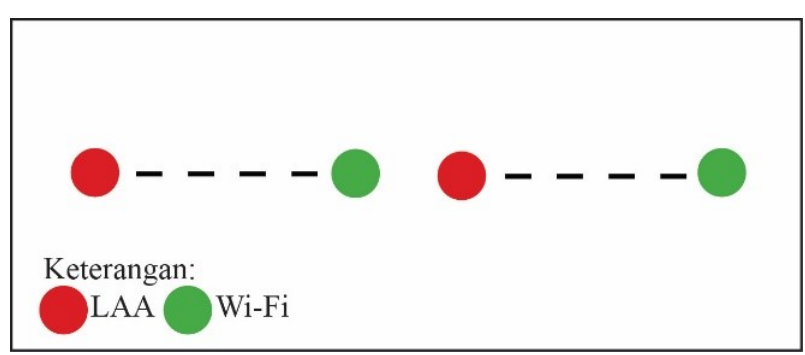

Gambar 5. Ilustrasi Penerapan LBT pada LAA

Gambar 5 menunjukan ilustrasi skenario 3 dengan penerapan mekanisme LBT. Skenario ini bertujuan untuk memperlihatkan sistem LAA yang bukan menjadi penginterferensi sehingga tidak menurunkan performansi Wi-Fi pada saat menggunakan kanal frekuensi yang sama. 


\subsection{Traffic Model}

FTP Traffic Model termasuk ke dalam burst traffic pattern yang merupakan level lalu lintas data yang tidak stabil atau data cenderung meledak, baik dalam keadaan normal maupun idle. FTP over TCP bertujuan untuk memastikan semua file dikirim dengan handal tanpa ada data yang gagal pada protokol TCP. Sedangkan, FTP over UDP akan mengirimkan file melalui protokol UDP, dengan throughput dan latency yang diukur pada lapisan IP. Alasan keduanya dibandingkan, karena kedua protokol ini digunakan untuk mengirim data (packet) melalui internet. Dengan kata lain, keduanya baik data TCP maupun UDP dikirim ke alamat IP. Selain itu, kedua protokol ini pula umum digunakan.

\section{Hasil Simulasi}

Data yang didapatkan dari hasil skenario simulasi dan pengujian akan dianalisis berdasarkan parameter KPI (QoS), yaitu throughput dan latency. Pada data hasil simulasi throughput diukur berdasarkan transport UDP dan TCP untuk masing-masing 3 skema penambahan pelanggan.

Tabel 3. Rekapitulasi FTP over UDP Skenario 1

\begin{tabular}{|c|c|c|c|c|c|}
\hline \multicolumn{2}{|r|}{ Parameter } & Max & Min & Mean & S. Dev \\
\hline \multicolumn{6}{|c|}{8 UE per Operator } \\
\hline A & \multirow{2}{*}{$\begin{array}{l}\text { Throughput } \\
\text { (Mbps) }\end{array}$} & 74.27 & 15.05 & 63.48 & 10.29 \\
\hline B & & 71.94 & 36.87 & 70.60 & 4.598 \\
\hline A & \multirow{2}{*}{ Latency (ms) } & 89.36 & 30.57 & 38.80 & 3.352 \\
\hline $\bar{B}$ & & 57.94 & 30.41 & 31.48 & 3.525 \\
\hline \multicolumn{6}{|c|}{20 UE per Operator } \\
\hline A & \multirow{2}{*}{$\begin{array}{l}\text { Throughput } \\
\text { (Mbps) }\end{array}$} & 73.34 & 44.19 & 65.48 & 5.19 \\
\hline B & & 71.9 & 70.79 & 71.33 & 0.327 \\
\hline $\mathrm{A}$ & \multirow{2}{*}{ Latency (ms) } & 82.39 & 32.53 & 38.12 & 9.177 \\
\hline $\mathrm{B}$ & & 57.94 & 30.50 & 31.58 & 3.681 \\
\hline \multicolumn{6}{|c|}{32 UE per Operator } \\
\hline A & \multirow{2}{*}{$\begin{array}{l}\text { Throughput } \\
\text { (Mbps) }\end{array}$} & 73.34 & 44.19 & 65.48 & 5.199 \\
\hline $\bar{B}$ & & 71.94 & 70.79 & 71.33 & 0.327 \\
\hline A & \multirow{2}{*}{ Latency (ms) } & 82.39 & 32.52 & 38.12 & 9.177 \\
\hline B & & 57.94 & 30.50 & 31.58 & 3.681 \\
\hline
\end{tabular}

Tabel 3, 4 dan 5 berturut-turut adalah rekapitulasi akhir simulasi FTP over UDP setiap skenario yang digunakan pada operator A dan operator B, didapatkan hasil terbaik menggunakan nilai lambda terendah 0.5 (pada skenario 3 atau penggunaan LBT). Selain itu, ED threshold yang ditetapkan pada simulasi ini memiliki nilai tertinggi yaitu $-62 \mathrm{dBm}$, yang artinya LBT memiliki nilai ambang batas yang tinggi yang dapat mempengaruhi tingginya parameter KPI yang didapatkan. Transport UDP ini merupakan full buffer yang memberikan kesempatan lebih pada LAA untuk mentransmit data dibandingkan Wi-Fi.

Pada hasil rekapitulasi dari Tabel 3, 4 dan 5 di atas dapat dilihat bahwa penggunaan mekanisme LBT pada
Tabel 4. Rekapitulasi FTP over UDP Skenario 2

\begin{tabular}{|c|c|c|c|c|c|}
\hline \multicolumn{2}{|r|}{ Parameter } & Max & Min & Mean & S. Dev \\
\hline \multicolumn{6}{|c|}{8 UE per Operator } \\
\hline A & \multirow{2}{*}{$\begin{array}{l}\text { Throughput } \\
\text { (Mbps) }\end{array}$} & 42.58 & 10.51 & 35.46 & 6.107 \\
\hline B & & 97.70 & 45.05 & 85.59 & 14.26 \\
\hline $\mathrm{A}$ & \multirow{2}{*}{ Latency (ms) } & 147.4 & 49.29 & 62.26 & 14.84 \\
\hline $\mathrm{B}$ & & 57.29 & 21.11 & 26.06 & 6.493 \\
\hline \multicolumn{6}{|c|}{20 UE per Operator } \\
\hline A & \multirow{2}{*}{$\begin{array}{l}\text { Throughput } \\
\text { (Mbps) }\end{array}$} & 42.58 & 7.310 & 35.76 & 6.542 \\
\hline $\mathrm{B}$ & & 97.65 & 45.95 & 85.04 & 14.09 \\
\hline $\mathrm{A}$ & \multirow{2}{*}{ Latency (ms) } & 315 & 49.29 & 64.38 & 8.401 \\
\hline $\mathrm{B}$ & & 56.53 & 21.20 & 26.21 & 6.500 \\
\hline \multicolumn{6}{|c|}{32 UE per Operator } \\
\hline $\bar{A}$ & \multirow{2}{*}{$\begin{array}{l}\text { Throughput } \\
\text { (Mbps) }\end{array}$} & 42.58 & 7.310 & 35.76 & 6.542 \\
\hline$\overline{\mathrm{B}}$ & & 97.65 & 45.95 & 85.04 & 14.09 \\
\hline A & \multirow{2}{*}{ Latency (ms) } & 315 & 49.29 & 64.38 & 8.401 \\
\hline B & & 56.53 & 21.20 & 26.21 & 6.500 \\
\hline
\end{tabular}

Tabel 5. Rekapitulasi FTP over UDP Skenario 3

\begin{tabular}{|c|c|c|c|c|c|}
\hline & Parameter & Max & Min & Mean & S. Dev \\
\hline \multicolumn{6}{|c|}{8 UE per Operator } \\
\hline A & \multirow{2}{*}{$\begin{array}{l}\text { Throughput } \\
\text { (Mbps) }\end{array}$} & 126.4 & 26.22 & 112.6 & 19.15 \\
\hline B & & 115.8 & 0.021 & 100.4 & 17.88 \\
\hline A & \multirow{2}{*}{ Latency (ms) } & 103.7 & 17.84 & 20.91 & 7.369 \\
\hline B & & 552.3 & 17.99 & 24.0 & 36.19 \\
\hline \multicolumn{6}{|c|}{20 UE per Operator } \\
\hline A & \multirow{2}{*}{$\begin{array}{l}\text { Throughput } \\
\text { (Mbps) }\end{array}$} & 126.3 & 26.22 & 112.0 & 18.72 \\
\hline $\bar{B}$ & & 114.3 & 0.021 & 99.63 & 18.36 \\
\hline A & \multirow{2}{*}{ Latency (ms) } & 60.04 & 17.86 & 20.88 & 5.012 \\
\hline B & & 552.3 & 18.09 & 26.83 & 50.79 \\
\hline \multicolumn{6}{|c|}{32 UE per Operator } \\
\hline A & \multirow{2}{*}{$\begin{array}{l}\text { Throughput } \\
\text { (Mbps) }\end{array}$} & 126.3 & 15.48 & 111.9 & 20.89 \\
\hline B & & 113.9 & 37.97 & 100.4 & 18.39 \\
\hline $\mathrm{A}$ & \multirow{2}{*}{ Latency (ms) } & 212.1 & 17.86 & 22.67 & 19.62 \\
\hline B & & 67.70 & 18.33 & 21.96 & 8.059 \\
\hline
\end{tabular}

skenario 3, meningkatkan throughput dan menurunkan latency yang signifikan dibandingkan skenario 1 dan 2 pada kasus jumlah pengguna 8, 20 maupun 32 untuk masing-masing operator. Selain itu, penggunaan LBT juga dapat menciptakan keadilan bagi operator A maupun B yang terlihat dari perbedaan nilai throughput dan latency yang tidak terlampau jauh pada setiap operator tersebut.

Dapat dilihat dari Gambar 6 dan Gambar 7, simulasi pada skenario 3 mendapatkan hasil throughput yang maksimal dan latency yang minimal. Hal ini disebabkan oleh penggunaan mekanisme LBT, sehingga penggunaan kanal frekuensi dapat digunakan secara bergantian antara LAA dan Wi-Fi dengan tidak saling menggangu satu sama lain. Adapun aspek keadilan pada jaringan dapat dilihat dengan menggunakan tabel jain 


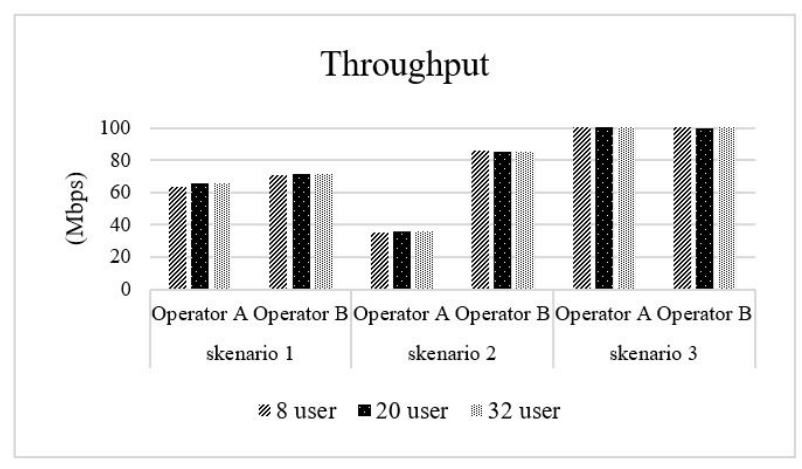

Gambar 6. Throughput FTP over UDP

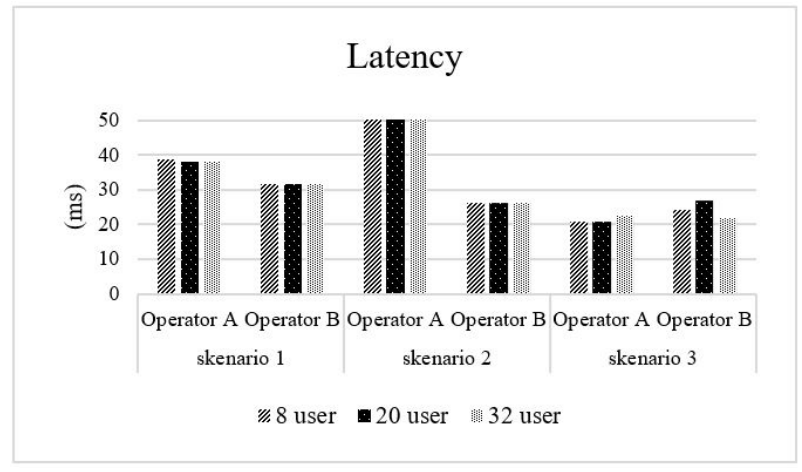

Gambar 7. Latency FTP over UDP

fairness index sesuai pada Tabel 6 di bawah ini.

Tabel 6. Jain Fairness Index FTP over UDP

\begin{tabular}{|c|c|c|c|}
\hline \multicolumn{4}{|c|}{ Throughput } \\
\hline UE & Skenario 1 & Skenario 2 & Skenario 3 \\
\hline 16 & 0.997 & 0.853 & 0.996 \\
\hline 40 & 0.998 & 0.857 & 0.996 \\
\hline 64 & 0.998 & 0.857 & 0.997 \\
\hline \multicolumn{4}{|c|}{ Latency } \\
\hline UE & Skenario 1 & Skenario 2 & Skenario 3 \\
\hline 16 & 0.989 & 0.856 & 0.995 \\
\hline 40 & 0.991 & 0.849 & 0.984 \\
\hline 64 & 0.991 & 0.849 & 0.999 \\
\hline
\end{tabular}

Dari data pada Tabel 6 didapatkan rata-rata nilai fairness mendekati 1. Dari ketiga skenario yang telah dikerjakan, skenario 3 (ideal) memiliki hasil simulasi dengan parameter KPI yang terbaik jika dibandingkan skenario yang lainnya. Hal ini dapat terjadi karena efisiensi dan penggunaan mekanisme LBT yang tepat. Selain itu, untuk kasus adanya interferensi dari sistem lain menjadikan tantangan sendiri dan membutuhkan mekanisme yang sesuai dengan lingkungan sistem tersebut. Penggunaan UDP umumnya digunakan sebagai protokol untuk VOIP, mengingat rendahnya latency yang dihasilkan.

Dari hasil tersebut, dapat dilihat bahwa penggunaan mekanisme LBT pada operator LAA dapat memperbaiki ketidakmampuan operator seluler pada penggunaan kanal frekuensi $5 \mathrm{GHz}$ terhadap operator Wi-Fi di tempat yang sama dengan jumlah node yang banyak pada skenario 2 dan 3. Penggunaan LBT dapat memperbaiki hal tersebut, jika dilihat dari performansi jaringan yang didapatkan oleh pengguna pada daerah dengan kepadatan pengguna yang tinggi baik pada operator LAA maupun Wi-Fi dengan tidak berdampak pada penurunan kemampuan masing-masing operator.

\subsection{FTP over TCP Application}

FTP menggunakan protokol Transmission Control Protocol (TCP) untuk melakukan komunikasi data antara klien dan server. Dari kedua komponen tersebut, dapat dibuat sebuah sesi komunikasi sebelum pengiriman data dimulai. Simulasi ini bertujuan untuk melihat penggunaan TCP yang umum digunakan sebagai protokol untuk melakukan download dan upload.

Tabel 7. Rekapitulasi FTP over TCP Skenario 1

\begin{tabular}{|c|c|c|c|c|c|}
\hline & Parameter & Max & Min & Mean & S. Dev \\
\hline \multicolumn{6}{|c|}{8 UE per Operator } \\
\hline A & \multirow{2}{*}{$\begin{array}{l}\text { Throughput } \\
\text { (Mbps) }\end{array}$} & 59.20 & 9.397 & 26.07 & 13.60 \\
\hline B & & 12.56 & 1.069 & 11.58 & 1.735 \\
\hline $\bar{A}$ & \multirow{2}{*}{ Latency (ms) } & 59.20 & 9.239 & 13.84 & 5.323 \\
\hline B & & 19.02 & 3.118 & 9.100 & 1.816 \\
\hline \multicolumn{6}{|c|}{20 UE per Operator } \\
\hline A & \multirow{2}{*}{$\begin{array}{l}\text { Throughput } \\
\text { (Mbps) }\end{array}$} & 47.37 & 1.446 & 37.68 & 8.098 \\
\hline $\mathrm{B}$ & & 12.56 & 1.069 & 11.58 & 1.735 \\
\hline A & \multirow{2}{*}{ Latency (ms) } & 26.38 & 9.239 & 13.33 & 3.070 \\
\hline B & & 19.02 & 3.118 & 9.100 & 1.816 \\
\hline \multicolumn{6}{|c|}{32 UE per Operator } \\
\hline A & \multirow{2}{*}{$\begin{array}{l}\text { Throughput } \\
\text { (Mbps) }\end{array}$} & 47.37 & 13.35 & 38.22 & 6.960 \\
\hline B & & 12.56 & 1.611 & 11.67 & 1.419 \\
\hline A & \multirow{2}{*}{ Latency (ms) } & 59.20 & 9.397 & 13.91 & 5.334 \\
\hline B & & 19.02 & 4.241 & 9.154 & 1.731 \\
\hline
\end{tabular}

Tabel 7, 8 dan 9 menjelaskan hasil rekapitulasi FTP over TCP pada masing-masing skenario, yang berarti paket mengalir melalui koneksi TCP. Transport TCP dideskripsikan sebagai finite buffer yang menyediakan kontrol aliran. Dapat dilihat bahwa fungsi throughput berbanding lurus dengan latency yang dihasilkan. Namun, skema ini menghasilkan KPI yang lebih rendah pada operator A (LAA) dibandingkan dengan skema UDP sebelumnya, karena finite buffer (buffer terbatas) memberikan kesempatan lebih pada operator Wi-Fi untuk dapat mentransmisikan data.

Dari rekapitulasi Tabel 7, 8 dan 9 tersebut, dapat dilihat bahwa skenario 1 menghasilkan nilai yang lebih baik pada operator A dibanding operator B. Skenario 2 menghasilkan nilai yang sebaliknya. Pada skenario 3, nilai pada operator A tidak lebih baik daripada operator 
Tabel 8. Rekapitulasi FTP over TCP Skenario 2

\begin{tabular}{|c|c|c|c|c|c|}
\hline \multicolumn{2}{|r|}{ Parameter } & Max & Min & Mean & S. Dev \\
\hline \multicolumn{6}{|c|}{8 UE per Operator } \\
\hline A & \multirow{2}{*}{$\begin{array}{l}\text { Throughput } \\
\text { (Mbps) }\end{array}$} & 10.39 & 0.006 & 7.119 & 3.051 \\
\hline B & & 69.19 & 27.60 & 54.65 & 10.00 \\
\hline $\mathrm{A}$ & \multirow{2}{*}{ Latency (ms) } & 38.81 & 8.432 & 19.15 & 5.802 \\
\hline $\mathrm{B}$ & & 14.37 & 5.320 & 9.014 & 1.842 \\
\hline \multicolumn{6}{|c|}{20 UE per Operator } \\
\hline A & \multirow{2}{*}{$\begin{array}{l}\text { Throughput } \\
\text { (Mbps) }\end{array}$} & 10.24 & 0.049 & 7.475 & 2.725 \\
\hline B & & 68.45 & 23.28 & 52.49 & 10.79 \\
\hline A & \multirow{2}{*}{ Latency (ms) } & 57.13 & 8.114 & 20.45 & 7.978 \\
\hline $\mathrm{B}$ & & 19.78 & 5.695 & 9.250 & 2.240 \\
\hline \multicolumn{6}{|c|}{32 UE per Operator } \\
\hline $\mathrm{A}$ & \multirow{2}{*}{$\begin{array}{l}\text { Throughput } \\
\text { (Mbps) }\end{array}$} & 10.24 & 0.049 & 7.536 & 2.651 \\
\hline $\mathrm{B}$ & & 68.45 & 23.28 & 52.96 & 9.622 \\
\hline A & \multirow{2}{*}{ Latency (ms) } & 57.13 & 8.114 & 20.62 & 7.978 \\
\hline $\mathrm{B}$ & & 13.78 & 5.695 & 9.332 & 2.070 \\
\hline
\end{tabular}

Tabel 9. Rekapitulasi FTP over TCP Skenario 3

\begin{tabular}{|c|c|c|c|c|c|}
\hline \multicolumn{2}{|r|}{ Parameter } & Max & Min & Mean & S. Dev \\
\hline \multicolumn{6}{|c|}{8 UE per Operator } \\
\hline A & \multirow{2}{*}{$\begin{array}{l}\text { Throughput } \\
\text { (Mbps) }\end{array}$} & 27.25 & 2.63 & 21.21 & 3.37 \\
\hline $\mathrm{B}$ & & 98.41 & 6.99 & 81.77 & 16.4 \\
\hline A & \multirow{2}{*}{ Latency (ms) } & 26.12 & 4.83 & 8.791 & 3.16 \\
\hline $\mathrm{B}$ & & 33.39 & 4.12 & 6.083 & 3.40 \\
\hline \multicolumn{6}{|c|}{20 UE per Operator } \\
\hline $\mathrm{A}$ & \multirow{2}{*}{$\begin{array}{l}\text { Throughput } \\
\text { (Mbps) }\end{array}$} & 26.49 & 3.63 & 21.24 & 2.78 \\
\hline B & & 97.89 & 6.99 & 81.34 & 15.8 \\
\hline $\mathrm{A}$ & \multirow{2}{*}{ Latency (ms) } & 21.58 & 6.05 & 8.960 & 3.04 \\
\hline $\mathrm{B}$ & & 24.78 & 4.19 & 6.083 & 2.81 \\
\hline \multicolumn{6}{|c|}{32 UE per Operator } \\
\hline A & \multirow{2}{*}{$\begin{array}{l}\text { Throughput } \\
\text { (Mbps) }\end{array}$} & 26.55 & 2.32 & 20.50 & 4.08 \\
\hline B & & 96.97 & 34.1 & 79.75 & 16.1 \\
\hline A & \multirow{2}{*}{ Latency (ms) } & 28.12 & 4.18 & 9.649 & 4.42 \\
\hline B & & 26.36 & 4.12 & 6.025 & 2.00 \\
\hline
\end{tabular}

B, namun nilai parameter yang dihasilkan untuk masing-masing jumlah pengguna didapatkan lebih baik apabila dibandingkan dengan skenario lain. Skenario 3 dengan jumlah pengguna 8 menghasilkan nilai terbaik dibandingkan dengan jumlah pengguna yang sama pada skenario lainnya.

Gambar 8 dan Gambar 9 menunjukkan hasil, simulasi pada skenario 3 yang memiliki nilai throughput yang maksimal dan latency yang minimal. Dari data tersebut dapat dilihat bahwa nilai throughput pada operator LAA cenderung dapat dipertahankan dengan penggunaan LBT (skenario 3) seperti pada skenario 1. Selain itu, nilai latency yang dihasilkan pada penggunaan LBT dapat diturunkan dengan kata lain didapatkan perbaikan dibandingkan skenario lainnya.

Tabel 10 menunjukan nilai jain fairness index yang

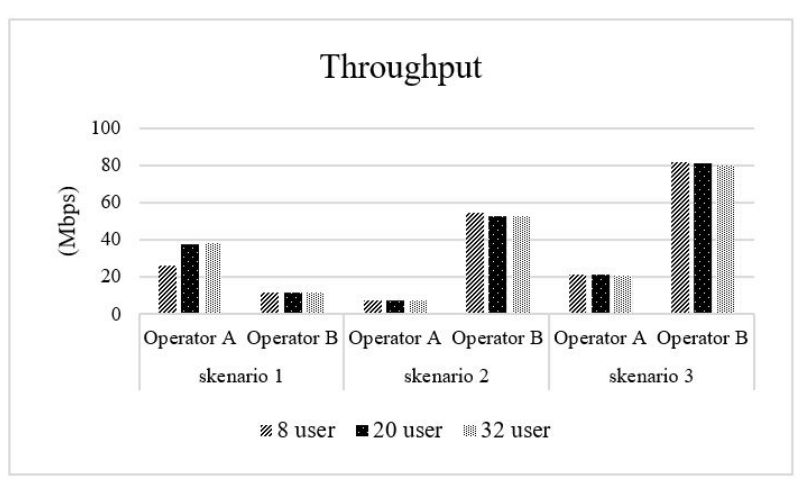

Gambar 8. Throughput FTP over TCP

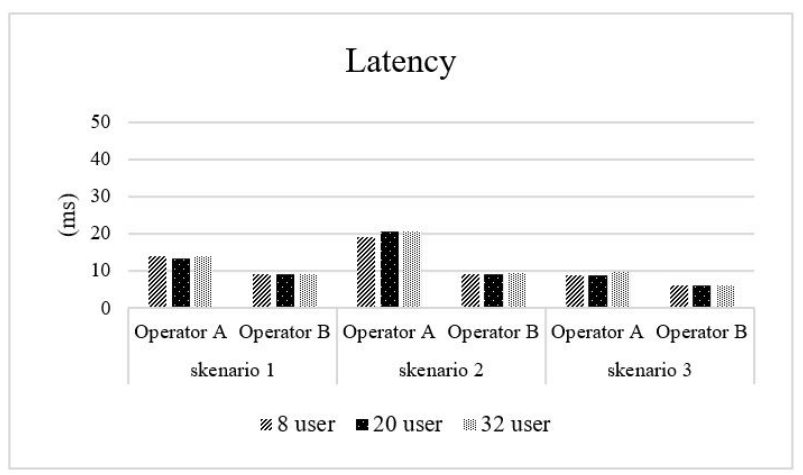

Gambar 9. Latency FTP over TCP

didapatkan pada simulasi FTP over TCP. Pada simulasi ini didapatkan hasil fairness yang lebih baik pada aspek latency dibangkan throughput. Tentunya hal ini berbanding terbaik dengan simulai pada FTP over UDP sebelumnya yang menghasilkan nilai fairness pada aspek throughput yang lebih baik. Dari hasil tersebut, dapat disimpulkan bahwa penggunaan LBT dapat memperbaiki hasil latency pada aplikasi UDP.

\section{Kesimpulan}

1. Penggunaan mekanisme LBT pada operator LAA dapat memperbaiki performansi, baik pada operator LAA itu sendiri maupun pada operator Wi-Fi. Hal ini dapat dilihat dari 2 hasil simulasi yang digunakan pada FTP over UDP maupun FTP over TCP. Penggunaan skenario 3 (LBT) dapat meningkatkan aspek throughput dan menurunkan aspek latency dibandingkan skenario lainnya.

2. Berdasarkan perhitungan Jains Fairness Index FTP over UDP yang didapatkan dari nilai KPI hasil simulasi, didapatkan lonjakan nilai throughput yang semakin tinggi pada skenario 3 dengan jumlah pengguna terbanyak (32 pengguna per operator) dibandingkan skenario lainnya dengan jumlah pengguna yang sama. Oleh karena itu, aplikasi UDP pada LBT dapat meningkatkan aspek throughput dengan jumlah pengguna yang 
Tabel 10. Jains Fairness Index FTP over TCP

\begin{tabular}{|c|l|l|l|}
\hline \multicolumn{4}{|c|}{ Throughput } \\
\hline UE & Skenario 1 & Skenario 2 & Skenario 3 \\
\hline 16 & 0.870 & 0.628 & 0.743 \\
\hline 40 & 0.780 & 0.639 & 0.744 \\
\hline 64 & 0.779 & 0.639 & 0.741 \\
\hline \multicolumn{4}{|c|}{ Latency } \\
\hline UE & Skenario 1 & Skenario 2 & Skenario 3 \\
\hline 16 & 0.959 & 0.885 & 0.967 \\
\hline 40 & 0.965 & 0.875 & 0.964 \\
\hline 64 & 0.959 & 0.875 & 0.949 \\
\hline
\end{tabular}

maksimal sesuai indikasi nilai fairness yang didapatkan sebesar 0.997 .

3. Berdasarkan perhitungan Jains Fairness Index FTP over TCP, didapatkan nilai latency yang semakin rendah pada skenario 3 dengan jumlah pengguna paling sedikit ( 8 pengguna per operator) dibandingkan skenario lainnya dengan jumlah pengguna yang sama. Oleh karena itu, aplikasi TCP pada LBT dapat menurunkan aspek latency dengan jumlah pengguna yang maksimal sesuai indikasi nilai fairness yang didapatkan sebesar 0.967 .

4. Aplikasi UDP pada LBT efektif digunakan pada kasus jumlah pengguna yang maksimal (32 pengguna per operator) berdasarkan indikasi meningkatnya aspek throughput, sedangkan aplikasi TCP efektif digunakan pada kasus jumlah pengguna yang minimal ( 8 pengguna per operator) berdasarkan indikasi menurunnya aspek latency dibandingkan dengan skenario non-LBT lainya

\section{Daftar Pustaka}

[1] "Study on licensed assisted access to unlicensed spectrum," 3rd Generation Partnership Project;
Technical Specification Group Radio Access Network, no. 3GPP TR 36.889 V13.0.0, Jun 2015.

[2] "Coexistence lessons learned," IEEE Project 802, no. IEEE 802.19-14/0080r2, 2014.

[3] "Study on licensed assisted using lte," 3GPP-TSGRAN-Meetin65, no. Tech. Rep. RP141664, Sep 2014.

[4] B. Chen, J. Chen, Y. Gao, and J. Zhang, "Coexistence of lte-laa and wi-fi on 5 ghz with corresponding deployment scenarios: A survey," IEEE Communications Surveys \& Tutorials, vol. 19, no. 1, pp. 7-32, 2016.

[5] L. Giupponi, T. Henderson, B. Bojovic, and M. Miozzo, "Simulating lte and wi-fi coexistence in unlicensed spectrum with ns-3," arXiv preprint arXiv:1604.06826, 2016.

[6] R. Zhang, M. Wang, L. X. Cai, Z. Zheng, X. Shen, and L.-L. Xie, "Lte-unlicensed: The future of spectrum aggregation for cellular networks," IEEE Wireless Communications, vol. 22, no. 3, pp. 150159, 2015.

[7] S. R. Group et al., "The prospect of lte and wi-fi sharing unlicensed spectrum," Wite Paper, pp. 1-17, 2015.

[8] [Online]. Available: https://www.nsnam.org/ overview/what-is-ns-3/

[9] "Further advancements for e-utra physical layer aspects," 3rd Generation Partnership Project; Technical Specification Group Radio Access Network, no. 3GPP TR 36.814 V9.2.0, Mar 2013. 